Editorial

\title{
The Promise and Perils of Direct Democracy: An Introduction
}

\author{
Todd Donovan \\ Political Science Department, Western Washington University, Bellingham, WA 98225, USA; \\ E-Mail: todd.donovan@wwu.edu
}

Submitted: 12 June 2019 | Published: 27 June 2019

\begin{abstract}
Direct democracy promises politics that improve links between citizens and their representatives, and satisfies popular demand for increased engagement. In practice it may fall well short, given limited citizen capacity, poor information from campaigns, and ill-designed processes. The articles here represent the opportunities that direct democracy offers for the study of these promises and perils.
\end{abstract}

\section{Keywords}

comparative politics; deliberation; direct democracy; initiatives; referendums; representation; secondary effects

\section{Issue}

This editorial is part of the issue "The Politics, Promise and Peril of Direct Democracy", edited by Todd Donovan (Western Washington University, USA).

(C) 2019 by the author; licensee Cogitatio (Lisbon, Portugal). This article is licensed under a Creative Commons Attribution 4.0 International License (CC BY).

\section{Introduction}

This issue of Politics and Governance includes a collection of articles examining direct democracy. The volume demonstrates the broad but by no means exhaustive range of topics and questions associated with referendums, initiatives and public deliberation. Many of the questions asked here-about voting, campaigns, inequality, minority rights, trust, and participation-may apply generally to the study of elections and representation. The context of direct democracy, however, provides a unique lens through which we might view these matters, as direct democracy brings with it a set of promises and perils distinct from representative democracy. The promise may be a politics that satisfies growing popular interest in politics (Tierney, 2012), or increases citizen engagement (Smith \& Tolbert, 2004), or provides better links between citizens and their representatives (Altman, 2010). Perils include limited citizen capacity, poor information, and ill-designed processes that may fall well short of filling these promises.

Not long ago direct democracy was seldom considered in the social sciences as the practice of direct democracy was less common. With increased use since the 1970s (Qvortrup, 2018), scholarly attention to direct democracy has also increased. Why more use and attention? Qvortrup (2018, p. 11) suggests that as people demanded more referendums, parties in government responded. Whatever the case, democratic practice and popular expectations changed. Several newer eastern European democracies use referendums regularly, and provisions for use of direct democracy expanded in Europe since 2000 (Colin, 2019). Groups outside of government have long championed the use of initiatives and referendums while established parties were less keen (Bowler, Donovan, \& Karp, 2006). But established parties are less dominant, with newer parties on the left (Podemos), right (UKIP, AfD), and Five Star Movement embracing direct democracy. The 2016 Brexit referendum is an example of the changed context-a polarizing vote on an issue divinding established parties internally, driven by a fringe party having scant representation in Parliament. That was much different than the 1975 UK vote on the Common Market, and certain to receive more academic attention.

Where studies of direct democracy were mostly limited to the American states and Switzerland, articles in this volume demonstrate that although Switzerland and the US continue to provide fertile ground for study, the scope here extends to Columbia, Ireland, Italy, Finland, 
Spain, the UK, and beyond. A number of these articles provide cross-national analysis, and most have a focus beyond Switzerland and the US. In addition to geographic breadth, several of these contributions can be seen as part of a third wave of social science literature on direct democracy. Some of the more influential early studies (e.g., Butler \& Ranney, 1978; Magelby, 1984) were broad in considering the promise and perils of direct democracy, offering numerous avenues of future study yet with such scope, there was limited empirical analysis of discrete questions. A second wave built on this, with more narrowly focused questions, and greater empirical rigor. These studies expanded our understandings of voter competence, voter decision-making, threats to minority rights, the role of organized interests, the policy consequences of direct democracy, and much more. The 'secondary effects' literature has also expanded since the early 2000s, with empirical studies testing if use of direct democracy could increase political interest, knowledge, trust, participation, and political efficacy (see Dyck \& Lascher, 2019, for a review). A third wave of research has been reexamining the assumptions, methods, and conclusions of earlier research on direct democracy.

\section{Secondary Effects of Direct Democracy}

Three articles in this volume reexamine the promise of secondary, or 'educative' effects of direct democracy. Some of the more frequently cited results from the secondary effects literature is that initiative use increases turnout, and, potentially, trust. Christensen (2019) examines the context of Finland's relatively new agenda initiatives to see if involvement can built trust and finds that signing initiatives may be associated with lower trustunless the initiative was approved. These results complement the "initiated distrust" findings of Dyck (2009), yet also suggest direct democracy can increase trust in some situations. Motos (2019) uses a much different approach in considering participatory opportunities provided by Podemos in Spain, concluding that Podemos' claims about participatory democracy are not translated into institutions capable of creating educational values associated with political participation. LaCombe and Juelich (2019) report results more consistent with previous studies finding a link between direct democracy and political engagement. They demonstrate that when questions on the ballot are of interest to younger voters in the US, turnout is greater among the young.

\section{Popular Interest in Direct Democracy}

Two of these articles consider popular interest in direct democracy. Studies have found widespread support for the use of referendums but there is not consensus on what this support reflects. Rojon, Rijken and Klandermans (2019) advance our understanding of this by examining how people respond to different modes of participatory decision making. They find that people have nuanced understandings of participating in public meetings versus binding or non-binding referendums and initiatives. Americans appeared less interested in public meetings than referendums and initiatives, and people in states with binding referendums and initiatives were less supportive of those than people living in states without binding votes. Advisory votes, moreover, may allay some public concerns about some of the perils of public incompetence. Bowler and Donovan (2019) consider public attitudes about direct democracy in Europe in terms what people might expect from referendums, and how people perceive that referendums are actually used in their country. Perceptions of actually having a say via referendum democracy fall short of expectations about democracy-a form of democratic disappointment-in countries with greater corruption and inequality, and among right-populist voters and those who distrust politicians.

\section{Voting and Campaigns}

Several articles in this volume expand our understanding the potential perils of referendum campaigns, and voting on referendums. Morsi and Masullo (2019) and Organ (2019) examine the role of campaign information in two high stakes cases. Morsi and Masullo's (2019) study of Columbia's peace referendum suggest one way to generate support for such proposals would be highlighting opportunities, rather than focusing on the possible risks. Organ (2019) considers the Brexit campaign and raises the question of how a government might regulate false statements. He contends laws should expanded opportunities to challenge false statements, and that expanded opportunities for deliberative democracy are needed during campaigns. In addition, Nai and i Coma (2019) use the lens of direct democracy to examine when Swiss referendum campaigns might 'go negative'. They find that frontrunners rarely go negative, that campaigns behind in the polls are more likely to go negative, and that personal attacks were more likely when the election day was close. Bernhard (2019) studies two Swiss asylum referendums to provide a rare analysis of the dynamics of coalition formation on referendum campaigns.

Three of these articles focus directly on voting. Leininger (2019) demonstrates that voting on a referendum having little to do with the economy-the 2016 Italian constitutional referendum - can be heavily structured by voters' evaluations of the economy. Quinlan, Elkink and Sinnott (2019) contribute another study of economic voting on referendums, focusing on two Irish referendums on the $\mathrm{EU}$-one before and one after the global financial crisis of 2008. They find the economy mattered in both but that sociotropic motivations were more critical after the global financial crisis. Tolbert and Witko (2019) ask when American voters might approving increased income taxes and find that, unlike a proposal that would have increased income taxes on every- 
one, lower income conservatives in California supported increased income taxes when the rich were targeted.

\section{Outputs: Inequality and Minority Rights}

The Tolbert and Witko (2019) article provides an example where referendums could potentially mitigate income inequality. Two other articles here examine the relationship between direct democracy and income inequality head on. Geißel, Krämling and Paulus (2019) find that 'bottom-up' referenda fostered socioeconomic equality, suggesting that low socioeconomical status groups can use direct democracy to advance their interests. However, they note such referendums hindered legal and political equality. In contrast, Dyck, Hussey and Lascher (2019) offer theoretical reasons to expect direct democracy should not lead to redistribution, and provide evidence that initiative use did not reduce income inequality in California. Veri (2019) complements Geißel et al. (2019) in finding that introducing citizenship rights through a popular initiative is likely to fail, unless the policy is not visible to voters.

\section{Conclusion}

The fifteen articles here are only a small sample of contemporary social science research on direct democracy. Articles such as these are typically appear one off in general political science journals, or specialized journals of elections, representation, and the like. When found in isolation, we might under estimate the scope of research questions available when politics is studied through the lens of direct democracy. By collecting these together here, we can better sense the scope of existing research on direct democracy and, hopefully, the potential for more.

\section{Acknowledgments}

The editor thanks the efforts of dozens of dedicated, anonymous reviewers, and the team at Cogitatio Press, for making this volume possible.

\section{Conflict of Interests}

The author declares no conflict of interests.

\section{References}

Altman, D. (2010). Direct democracy worldwide. Cambridge: Cambridge University Press.

Bernhard, L. (2019). Intra-camp coalitions in direct democracy: Evidence from referendums on asylum. Politics and Governance, 7(2), 297-305.

Bowler, S., \& Donovan, T. (2019). Perceptions of referendums and democracy: The referendum disappointment gap. Politics and Governance, 7(2), 227-241.

Bowler, S., Donovan, T., \& Karp, J. A. (2006). Why politi- cians like electoral institutions: Self-interest, values, or ideology? The Journal of Politics, 68(2), 434-446.

Butler, D., \& Ranney, A. (1978). Referendums: A comparative study of practice and theory (Vol. 216). Washington, DC: AEI Press.

Christensen, H. S. (2019). Boosting political trust with direct democracy? The case of the Finnish Citizens' Initiative. Politics and Governance, 7(2), 173-186.

Collin, K. (2019). Populist and authoritarian referendums: The role of direct democracy in democratic deconsolidation. Washington, DC: Brookings Institution.

Dyck, J. J. (2009). Initiated distrust: Direct democracy and trust in government. American Politics Research, 37(4), 539-568.

Dyck, J. J., \& Lascher, E. L. (2019). Initiatives without engagement: A realistic appraisal of direct democracy's secondary effects. Ann Arbor, MI: University of Michigan Press.

Dyck, J. J., Hussey, W., \& Lascher, E. L. (2019). American state ballot initiatives and income inequality. Politics and Governance, 7(2), 381-410.

Geißel, B., Krämling, A., \& Paulus, P. (2019). It depends...Different direct democratic instruments and equality in Europe from 1990 to 2015. Politics and Governance, 7(2), 366-380.

LaCombe, S. J., \& Juelich, C. (2019). Salient ballot measures and the millennial vote. Politics and Governance, 7(2), 198-212.

Leininger, A. (2019). Economic voting in direct democracy: A case study of the 2016 Italian constitutional referendum. Politics and Governance, 7(2), 306-333.

Magleby, D. B. (1984). Direct legislation: Voting on ballot propositions in the United States. Baltimore, MD: Johns Hopkins University Press.

Morisi, D., \& Masullo, J. (2019). Risks and opportunities of direct democracy. The effect of information in Colombia's peace referendum. Politics and Governance, 7(2), 242-267.

Motos, C. R. (2019). 'Let the citizens fix this mess!' Podemos' claim for participatory democracy in Spain. Politics and Governance, 7(2), 187-197.

Nai, A., \& i Coma, F. M. (2019). Losing in the polls, time pressure, and the decision to go negative in referendum campaigns. Politics and Governance, $7(2)$, 278-296.

Organ, J. (2019). Legal regulation of campaign deliberation: Lessons from Brexit. Politics and Governance, $7(2), 268-277$.

Quinlan, S. Johan Elkink, J., \& Sinnott, R. (2019). Economic voting in EU referendums: Sociotropic versus egocentric voting in the Lisbon two treaty plebiscites in Ireland. Politics and Governance, 7(2), 334-350.

Qvortrup, M. (Ed.). (2018). Referendums around the world. Cham: Palgrave Macmillan.

Rojon, S., Rijken, A. J., \& Klandermans, B. (2019). A survey experiment on citizens' preferences for 'vote-centric' vs. 'talk-centric' democratic innovations with advisory vs. binding outcomes. Politics and Governance, 
$7(2), 213-226$.

Smith, D. A., \& Tolbert, C. (2004). Educated by initiative: The effects of direct democracy on citizens and political organizations in the American states. Ann Arbor, MI: University of Michigan Press.

Tierney, S. (2012). Constitutional referendums: The theory and practice of republican deliberation. Oxford: Oxford University Press.
Tolbert, C., \& Witko, C. (2019). Public support for higher taxes on the wealthy: California's Proposition 30. Politics and Governance, 7(2), 351-365.

Veri, F. (2019). Explaining foreigners' political rights in the context of direct democracy: A fuzzy-set QCA of Swiss cantonal popular votes. Politics and Governance, 7(2), 411-427.

\section{About the Author}

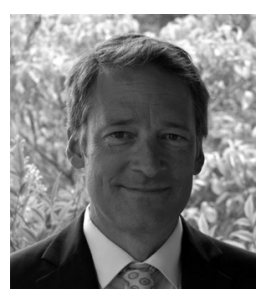

Todd Donovan is Professor of Political Science at Western Washington University. His research examines political behavior, representation, and electoral institutions, as well as public opinion, and direct democracy. He has authored, co-authored, and co-edited a dozen books, and has also advised media and state and federal courts on election matters. 